\title{
Current research trends in aluminum alloys for a high-pressure hydrogen gas container
}

\author{
Keitaro HORIKAWA*
}

Keywords: high-pressure hydrogen, fuel cell vehicle, aluminum alloy, hydrogen embrittlement, slow strain rate test

\section{1.はじめに}

地球温暖化の抑制に直接繋がる, 環境中への二酸化炭素排 出量の削減を目的として, あるいは, 将来の石油資源の枯渇 の問題にも対応するために, 従来の化石燃料の代替として, 水素エネルギーを有効活用する技術の開発が国内外で精力的 に進められている。自動車業界で進められている燃料電池自 動車（Fuel Cell Vehicle, FCV）の開発はその代表的なものであ り, FCV 自体は, 2010 年現在, 日本国内ですでに官公庁や一 般法人に限定したリース販売が行われており, 公道を走行し ている実績を有する ${ }^{1)}$ 。FCV は，（1）走行時に有害ガスを排 出しない,（2）エネルギー効率がガソリン車の 2 倍ほど高い, （3）ガソリン車並みに短時間での燃料充填が可能, など多く のメリットをむつ。しかしながら，FCVの車体製造コストの 低減, 車体の性能・安全確保, 水素ステーション建設のイン フラ整備問題など, 燃料電池車の更なる汎用化の促進のため には，まだまだ解決すべき様々な課題を抱えているのが現状 である。そのなかでも，燃料となる水素ガスの燃料電池車へ の搭載の問題が大きな壁の一つとなっている。ここでは, FCV 用の水素貯蔵容器の部材として開発が行われている 6000 系 (Al-Mg-Si 系) および 7000 系（Al-Zn- $\mathrm{Mg}$ 系）を中心とした アルミニゥム合金の研究の動向について紹介する。

\section{FCV 用高圧水素ガス貯蔵容器}

燃料電池自動車への水素の搭載方法としては，(1) 高圧水 素ガス，(2）液体水素，（3）水素吸蔵合金，などが検討され ているが, 取扱いの容易さや軽量化の面から高圧水素ガスに よる水素貯蔵が主に採用されており，そのための高圧水素ガ スタンクが開発されている ${ }^{2)}$ 。現状の一般的なガソリン車で は, 一度のガソリン充填でおよそ $500 \mathrm{~km}$ 走行が可能である が，燃料電池車がそれと同じ距離を走行するためには，約 $5 \mathrm{~kg}$ の水素ガスが必要となるとされている。たとえば $35 \mathrm{MPa}$ の高压ガスタンクを用いて, $5 \mathrm{~kg}$ の水素ガスを貯蔵するため には, 水素の体積は約 200 リットルとなり, ガソリン車の燃 料タンク（約 50 リットル）の 4 倍になり, 自動車車内の居 住空間を圧迫する。自動車メーカによって異なるが, 現在,

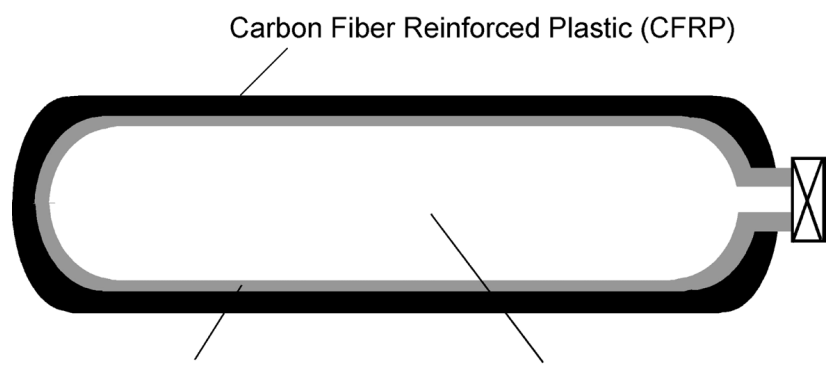

Aluminum Alloy Liner High-Pressure Hydrogen Gas

図 1 高圧水素ガス容器（VH3）の模式図

$35 \mathrm{MPa}$ (350 気圧)，あるいは $70 \mathrm{MPa}$ (700 気圧）といった高 圧タンクを用いて水素を貯蔵することが検討されている。夕 ンクの耐圧を $35 \mathrm{MPa}$ から $70 \mathrm{MPa}$ に上げることができれば, 単純計算により同重量の水素ガスを搭載できるタンク容量を 半分にすることが可能となる。

現在実用化されている金属製ライナを用いる高圧水素ガス 貯蔵容器 ${ }^{3)}$ (VH3) は, 図 1 の模式図に示すように, 水素ガ スを気密保持するためのライナ周囲を炭素繊維強化樹脂 (CFRP) で巻付けて強化した 2 層構造となっている。アルミ 二ウム合金は, 鉄系の材料と比べて, 水素ガスに対する気密 性や軽量性に優れていることから，この金属製ライナ材の有 力な候補材料となっている。ライナ材以外にもタンクに取付 けられるバルブや配管の材料としての用途拡大も期待されて いる。

\section{3. 現行の高圧水素用アルミニウム合金}

現行の圧力容器基準 JARI-S0014) では，アルミニウム材料 の中では 6061 合金 T6 材のみが, 燃料電池車に搭載される金 属製の高压水素タンクライナ材として規定されている。近年 の燃料電池自体の高効率化によって, $35 \mathrm{MPa}$ の高圧水素タン クでも, ガソリン車と同程度の航続距離をもつ燃料電池自動 車が開発されつつあるが, さらなる軽量化, 高効率化を目的 として, $70 \mathrm{MPa}$ 以上の充填圧の超高圧水素ガスタンクの開発 屯進められている ${ }^{3)}$ 。70 MPa を超える高压の水素環境でも耐 え得る性能を現行の 6061 合金を用いて確保する場合，アウ

\footnotetext{
* 大阪大学大学院基礎工学研究科 機能創成専攻（～560-8531 大阪府豊中市待兼山町 1-3)。Graduate School of Engineering Science, Osaka University (1-3 Machikaneyama, Toyonaka-shi, Osaka, 560-8531). 受付日: 平成 22 年 4 月 19 日 受理日 : 平成 22 年 5 月 26 日
} 
夕材に用いられる FRP 強化繊維を含めて, 肉厚を大きくする 必要が生じる。その結果, タンク単位重量あたりの水素充填 量の増加分に対して, タンクのコスト上昇が顕著となり, 経 済的に不利になることも起こり得る。したがって，補強材の 減量, 低コスト化およびライナ材の薄肉軽量化のためにも, 優れた耐水素脆化特性を持つ更なる高強度アルミニウム合金 の開発が望まれている。

\section{4. アルミニゥム合金の水素脆化感受性試験}

アルミニウム合金に限らず，金属材料のほとんどは水素に よって脆化することが知られているため，水素環境での安全 性の確認が必要である。高圧水素ガス環境を模擬したアルミ ニウム合金の水素脆化感受性の評価の簡便なスクリーニング 試験として，湿度制御雾囲気での低ひずみ速度引張試験法 ${ }^{5)}$ (Slow Strain Rate Test, SSRT) がある。SSRTによってアルミ ニウム合金の表面で生じる反応を図 2 の模式図に示す。低ひ ずみ速度で変形中に連続的に露出する新生アルミニウム合金 表面と雾囲気に含まれる水蒸気との化学反応により発生する 水素を利用することにより，高圧水素ガスに相当する環境を 簡便に模擬することが可能であると考えられている ${ }^{6)}$ 。SSRT では, 液体の水分が関与しないため, 水蒸気による表面の酸 化以外の, アノード溶解のような腐食の影響を受けずに, 材 料固有の水素脆性を評価できるものと考えられる。熱力学的 計算に基づく Young らの報告 ${ }^{7}$ によると, 湿潤環境の SSRT において，アルミニウム新生面と水との反応で生じる水素圧 （フガシティ）は $10^{67} \mathrm{~Pa}$ にも達するとされており，アルミニ ウム合金に水素脆化を引起こす外部環境として水または水蒸 気の影響が強く，水素ガス自体の害は比較的低いと見なされ ている ${ }^{8)}$ 。このことから, 大気圧・湿潤環境での SSRT は, 高圧水素環境での SSRTよりもより厳しい水素侵入環境での 試験法という位置づけとなっている。しかしながら，高圧下 での水素の作用についてはこれまで報告例が少ない状況にあ る。この状況に対して, 実際の高圧ガス環境と湿度制御雾囲 気の相関について現在調査が行われており, 高圧水素環境試 験のスクリーニングテストとしての位置づけの SSRT の有効 性の裏付けが並行して進められている ${ }^{9)}$ 。

この SSRT では, 引張特性のうち, とくに伸びに及ぼす水 素の影響を合金間で評価するために，次の式（1）で計算さ れるような水素脆化感受性指数がよく用いられる ${ }^{6), 10)}$ 。

$$
I(\delta)=\frac{\delta_{\mathrm{RH} 90 \%}-\delta_{\mathrm{DNG}}}{\delta_{\mathrm{DNG}}}
$$

ここで， $\delta_{\mathrm{DNG}}$ は乾燥窒素ガス（Dry Nitrogen Gas, DNG）中に おける伸び， $\delta_{\mathrm{RH} 90 \%}$ は，相対湿度 $90 \%(\mathrm{RH} 90 \%)$ 大気中での 伸びを示す。この指数は不活性な環境である DNG 中におけ る伸びを基準としたときの，RH90\% での水素脆化環境での 伸びの低下割合を示すむのであり，水素脆化が見られる場合 には正の值をとり，水素脆性を示さない場合はゼロあるいは それ以下の值をとる。水素の影響が小さい場合でも指数が数 值に反映されやすく, 脆化の有無の判定が容易であるという 利点がある。

一方で, 高圧水素ガス容器ライナ部材では, 長期にわたる 高圧水素環境での水素の充填, 放出の繰返しによる疲労の問 題も懸念されており, 特にライナ材の使用状況を想定した,

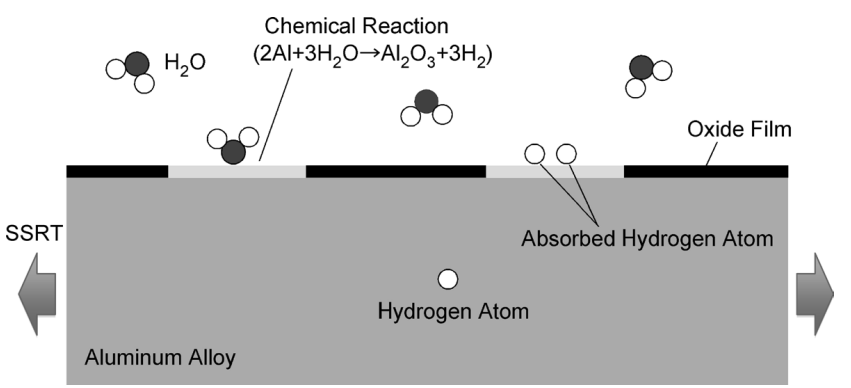

図 2 湿度制御環境での低ひずみ速度試験（SSRT）時の アルミニウム表面状況の模式図

疲労き裂進展に対する特性の評価および水素脆化の関与を明 らかにすることも重要課題の一つとなっている。例えば，車 載用高圧水素容器に対して，1 日に 2 回の水素充填を 15 年間 行った場合を想定すると， ライナ材への圧力变動は $1.1 \times 10^{4}$ 回となる。このことから, 圧力容器基準 JARI-S001 において 屯常温圧力サイクル数は 11250 回と定められている ${ }^{4)}$ 。また, 想定されている水素の充填による昇圧と水素の使用による減 圧のサイクルはかなり低速（1充填あたりで数〜10 分程度） となることから, 高圧水素環境での疲労特性に及ぼす周波数 の影響屯調查されている。有限寿命設計を想定したライナ材 の疲労特性として, $1 \mathrm{~Hz}$ 以下の低い周波数での $10^{4}$ サイクル 程度までの低サイクル疲労特性を高めることが特に有効であ ると考えられている。

また水素充填, 放出が繰返されることによって, 仮にライ ナ材に疲労き裂が発生, 進展した場合でも, 破裂に先んじて 水素が外部に漏れる LBB（Leak Before Burst）特性を確保す るために, 勒性を無視したライナ材の高強度化は危険である ことも指摘されている。金属材料の勒性は一般に平面ひずみ 破壊䩲性值 $K_{\mathrm{IC}}$ で評価されることが多いが，アルミニウム合 金については, 一部の高強度合金を除いて $K_{\mathrm{IC}}$ を求めること が困難であるため, 平面ひずみ破壊勒性試験に変わるアルミ ニウム合金の䩲性試験として, ASTM B871 による引裂試験法 での評価が広く行われている ${ }^{10)}$ 。また, 疲労き裂進展試験に ついては, 水素導入のために試験環境を調整することを除け ば，CT 試験片を用いた一般的な ASTM 規格 E647に準拠し た評価が行われている ${ }^{10)}$ 。

\section{5. 高圧水素用 6000 系アルミニゥム合金の開発 ${ }^{10)}$}

前述のとおり, 現在, 高圧水素用圧力容器ライナとして使 用されているのは 6061 合金 $\mathrm{T} 6$ 材のみであるが, 耐水素脆化 特性を維持しながら高強度を示す 6000 系合金の開発を目的 として, JIS 規格範囲内に拈いて，6061 合金の水素脆化感受 性に及ぼす合金成分の影響（ $\mathrm{Mg}, \mathrm{Si})$ が調査されている。図 3 に示すように JIS 規格で定められている 6061 合金の組成範 囲には $\mathrm{Mg}, \mathrm{Si}$ 量に幅がある。表 1 は, JIS 規格内での 6000 系 合金の水素脆化感受性に及ぼす組成の影響をまとめたもので ある。 $\mathrm{V}$ 添加組成や高 $\mathrm{Mg}$, 高 $\mathrm{Si}$ 組成で脆化感受性指数がわ ずかに正の值（それぞれ，0.09，0.08）となっているが，その 值自身む 0.1 未満と極めて小さいため，ほぼすべての 6061 合 金組成において, 水素脆化は生じないという判定がなされて いる。なお，一部合金においては，水素脆化感受性指数が負 となっているが, その原因として, 固溶水素が転位の移動度 


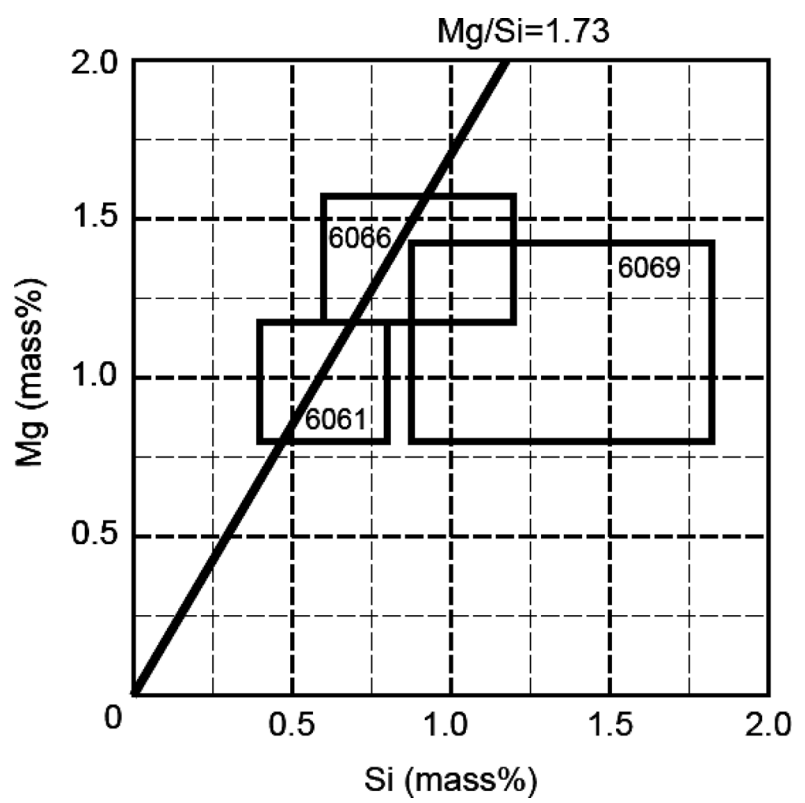

図 36000 系合金の規格組成

表 16061 アルミニウム合金の水素脆化感受性に及 ぼす合金組成 (mass\%) の影響 10)

\begin{tabular}{c|l|l|l|c|r}
\hline \hline No. & \multicolumn{1}{|c|}{$\mathrm{Si}$} & $\mathrm{Fe}$ & $\mathrm{Mg}$ & 備考 & $I(\boldsymbol{\delta})$ \\
\hline $\mathrm{A}$ & 0.65 & 0.30 & 1.03 & 低 $\mathrm{Si}$ & -0.05 \\
$\mathrm{~B}$ & 0.8 & 0.29 & 1.01 & 過剰 $\mathrm{Si}$ & -0.05 \\
$\mathrm{C}$ & 0.66 & 0.29 & 1.01 & 低 $\mathrm{Si}(+0.14 \mathrm{~V})$ & 0.09 \\
$\mathrm{D}$ & 0.64 & 0.05 & 1.04 & 低 $\mathrm{Fe}$ & -0.05 \\
$\mathrm{E}$ & 0.69 & 0.29 & 1.22 & 高 $\mathrm{Mg} \mathrm{Si}_{2}$ & 0.02 \\
$\mathrm{~F}$ & 0.66 & 0.71 & 1.05 & 高 $\mathrm{Fe}$ & -0.02 \\
$\mathrm{G}$ & 0.67 & 0.29 & 1 & 高 $\mathrm{Zn}(+0.24 \mathrm{Zn})$ & 0.02 \\
$\mathrm{H}$ & 1.26 & 0.27 & 0.38 & 高 $\mathrm{Si}$ 低 $\mathrm{Mg}$ & 0 \\
$\mathrm{I}$ & 1.26 & 0.28 & 1.21 & 高 $\mathrm{Si}$ 高 $\mathrm{Mg}$ & 0.08 \\
\hline
\end{tabular}

$0.32 \mathrm{Cu}, 0.17 \mathrm{Cr}, 0.05 \mathrm{Mn}$ は共通

を促進することに起因する水素助長局所塑性（Hydrogen

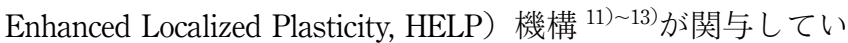
る可能性も指摘されている。

一方, 車載高圧容器の想定される使用温度範囲は最大 $85^{\circ} \mathrm{C}$ 程度までとされているため, 水素脆化感受性に対する温度の 影響についても調查が行われている。アルミニウム合金の応 力腐食割れ（SCC）き裂成長速度は室温以上の高温で促進さ れることが多く報告 ${ }^{14)}$ されているため, 室温以上での脆化感 受性の評価が特に重要となっている。各試験温度での RH65\% 大気環境での SSRT の結果によると，6061 合金 T6 材では $80^{\circ} \mathrm{C}$ まで水素脆化を生じないのに対して，7075 合金 $\mathrm{T} 6$ 材で は温度上昇に伴い水素脆化感受性が高まることが明らかにさ れている。

高圧水素ガス容器では, ライナの製造行程において容器口 金部は温間成形されるため, 溶体化処理後の結晶粒組織が粗 大化し, それによる強度低下, 勒性（延性）低下, 而水素脆 性特性の低下が懸念されている。そのため, 容器の組織状況 を想定した，6061-T6 合金の水素脆化感受性に対する結晶粒 サイズ，材料の肉厚，表面欠陥（切欠き）といった影響の調 查も行われている。通常レベルの粒径 $20 \mu \mathrm{m}$ を基準にすると,

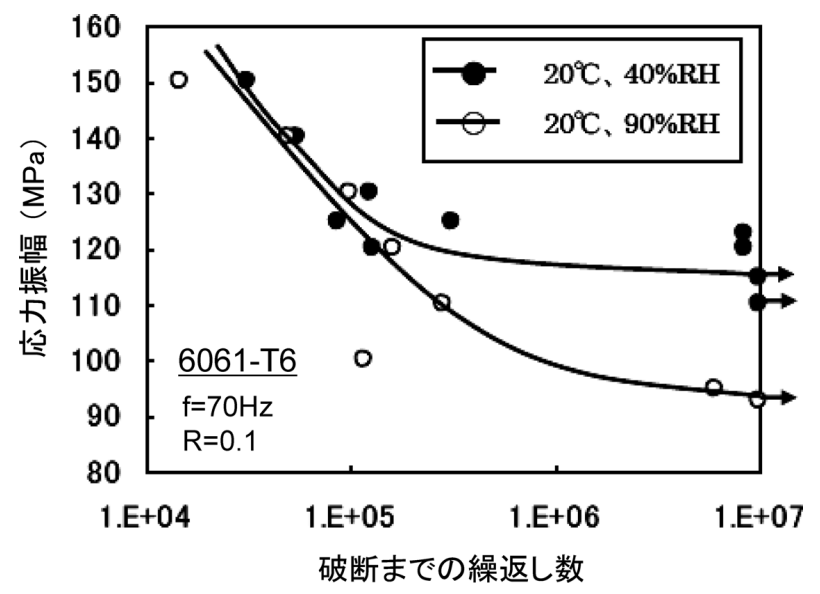

図４６061 上限成分合金の S-N 曲線に及ぼす環境湿度の 影響 10)

その約 20 倍の大きさの粗大結晶粒（ $(d=400 \mu \mathrm{m} ）$ としたとき に, 脆化感受性指数が 0.21 となり, 水素脆化傾向が認められ ることが示されている。すなわち, 結晶粒の粗大化は 6061 合 金の水素脆化を促進する要因となり得ると考えられている。 一方，肉厚の影響については，7075 合金 $\mathrm{T} 6$ 材では，板厚を $5 \mathrm{~mm}$ から $1 \mathrm{~mm}$ に薄肉にすることによる脆化感受性の高まり が示されているが，6061 合金 T6 材ではそのような板厚の違 い（1 $\mathrm{mm}$ と $5 \mathrm{~mm} ）$ による水素脆化感受性の違いは見られな いことも確認されている。なお， 7075 合金 T6 材の薄肉化に よって脆化感受性が高まる理由としては, 破面全体に占める 粒界割れ領域の割合の増加が関係しているためとされている。 また，切欠きを有する 6061 合金 T6 材では，高湿度環境にお ける SSRT で水素脆化は生じないこと屯確認されている。

6061 合金の疲労変形特性に対する水素の影響についても評 価が行われている。図 4 に示す疲労試験結果は一定応力振 幅, 周波数 $70 \mathrm{~Hz}$, 応力比 0.1 で求められた 6061 合金の上限 成分合金の S-N 曲線である。SSRT の場合と同じく，水素の 影響は試験環境の相対湿度の大きさで調整されている。上限 成分組成の 6061 合金では，環境中の相対湿度の増加により， $10^{4}$ 回までの低サイクル疲労での影響はほとんど見られない あのの, 高サイクル疲労において疲労強度（107 回での応力 振幅值）の低下が生じることが示されている。しかしながら， 車載用高圧水素容器の実使用環境で問題となるのは $10^{4}$ 回程 度までの低サイクル疲労であるため, 図 4 にみられる高サイ クル側 $\left(10^{7}\right.$ 回) での疲労強度の低下は問題とはならないと されている。なお，この 6061 合金の上限組成材は中心組成 材と比べて, 疲労における水素脆化感受性（相対湿度变化に 伴う疲労強度の変化率) が 2.5 倍程度, 増大することも報告 されている。

以上までの一連の高湿度大気中の SSRT により，6061 合金 T6 材は水素脆化感受性が低いと判断されている。そこで確 認のために 6061 合金 $\mathrm{T} 6$ 材，および比較材の 7075 合金 T6 材 について, 高圧水素ガス環境（85MPa）での SSRT と高湿度 大気中の SSRT とで脆化感受性の比較が行われている。図 5 は種々の環境で低ひずみ速度での SSRTにより求めた伸びの 脆化感受性 $I(\delta)$ を整理したものである。環境は $30^{\circ} \mathrm{C}$, RH $40 \% \sim 90 \%$ 大気，純水（Pure Water, PW）抢上び高圧 $85 \mathrm{MPa}$ 水素ガスである。高圧水素ガス中での SSRT では, 基 


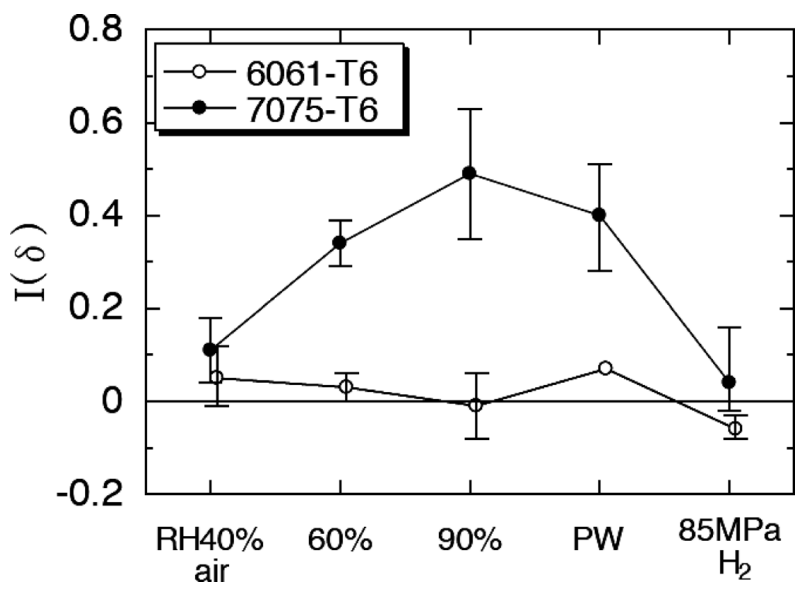

図 5 異なる環境におけるSSRTで求められた水素脆化 感受性指数 ${ }^{10)}$

準環境は高圧（85MPa）の窒素ガスとしている。その結果， 7075 合金 T6 材では RH90\% の大気中の SSRT で最も高い脆化 感受性 $I(\delta)=0.49$ を示したのに対して, $85 \mathrm{MPa}$ 水素ガス中で は, $I(\delta)=0.06$ と低く, 水素脆化は観察されていない。一方, 6061-T6 合金では，いずれの環境（高湿度大気，85MPa 高圧 水素ガス）の SSRTにおいても，脆化は生じないことが確認 されている（高圧水素中で， $I(\delta)=-0.06 ） 。 6061-\mathrm{T} 6$ および 7075-T6 両合金いずれも脆化をもたらす水素供給環境として, 高圧水素ガスは, 高湿度大気に比べて, その有害性は極めて 小さいことが確認されている。また，6061 中心組成の $\mathrm{Mg}$ 量 をべースにして，規格組成範囲内で最大の $\mathrm{Si}$ 量を含有する高 強度合金（6061HS と呼ぶ）においても，90 MPa 高圧水素ガ ス中での SSRT, 疲労試験, 疲労き裂進展試験が実施されて いるが，そのいずれの場合でも水素脆化は生じず，疲労特性 にも影響が見られないことが確認されている。

一方, 6061 合金以外の高強度化 6000 系合金の適用可能性 を調査するために，高合金組成で $\mathrm{Cu}, \mathrm{Mn}$ が添加された 6066 合金, および高 $\mathrm{Cu}$ 添加組成の 6069 合金の水素脆化感受性に ついても調査が行われている。これら合金では，伸びの脆化

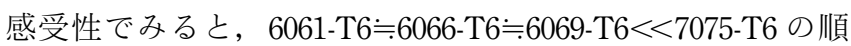
となることが示されている。したがって，T6材同士で比較す ると 6066 合金および 6069 合金の脆化感受性は 6061 合金と匹 敵するほど低いことがわかる。また， 6066 および 6069 合金 の高湿度環境下での疲労特性は 6061 合金之同等あるいはそ れ以上という判定むなされている。しかしながら, 図 6 に示 すように 6066 合金では不純物 $\mathrm{Fe}$ 量が $0.2 \%$ 以上になると脆 化感受性が高くなり， 0.44\% 含む 6066-T6 では， 7075-T6 と同 程度まで高い脆化感受性を示すため注意が必要となる。この 原因としては, Fe 系晶出物と母相の界面が水素侵入経 路 ${ }^{15), 16)}$ となって, 水素侵入量の増加に繋がっていることが 関係していると推測されている。また, 不純物 $\mathrm{Fe}$ 量が増加 すると, 引裂試験で求められる破壊勒性の低下が生じること 屯報告されている。したがって, 高圧水素貯蔵ライナに 6066 合金を選択する際には，合金中の Fe 量を低く抑えることも 重要であると考えられている。なお，図７に示す RH90\%で 行われた 6000 系合金（いずれも $\mathrm{T} 6$ 材）の疲労き裂進展試験 （周波数 $10 \mathrm{~Hz}$ ）の結果では, 疲労き裂進展速度は, 7075 > 6066>6069>6061 の順となり，6000 系合金はすべて 7075 合金

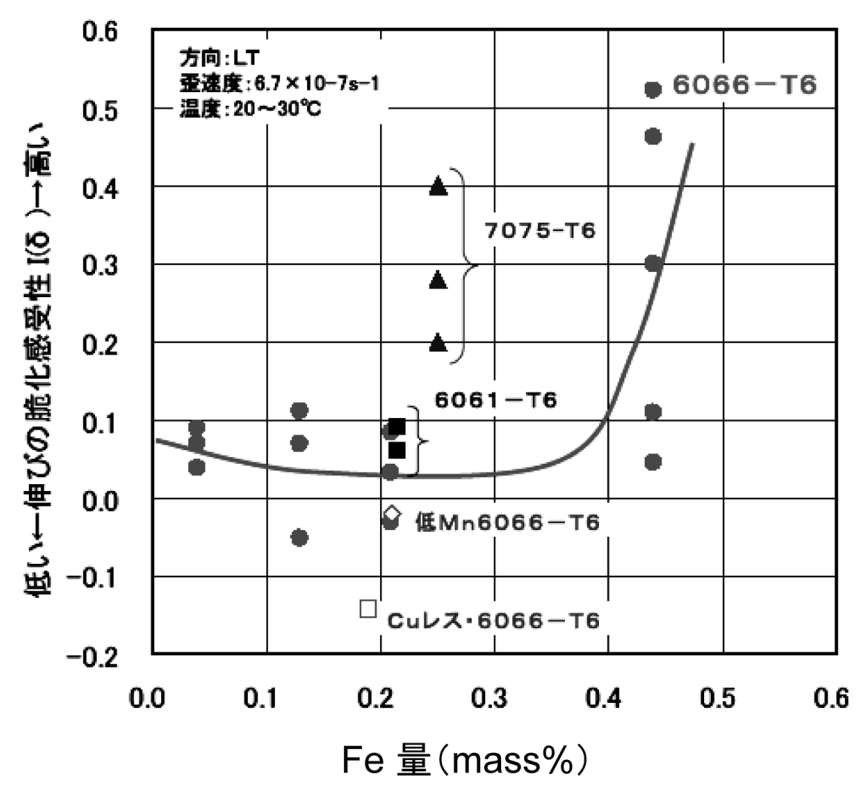

図 66066 合金の水素脆化感受性と不純物 Fe の関係 ${ }^{10)}$

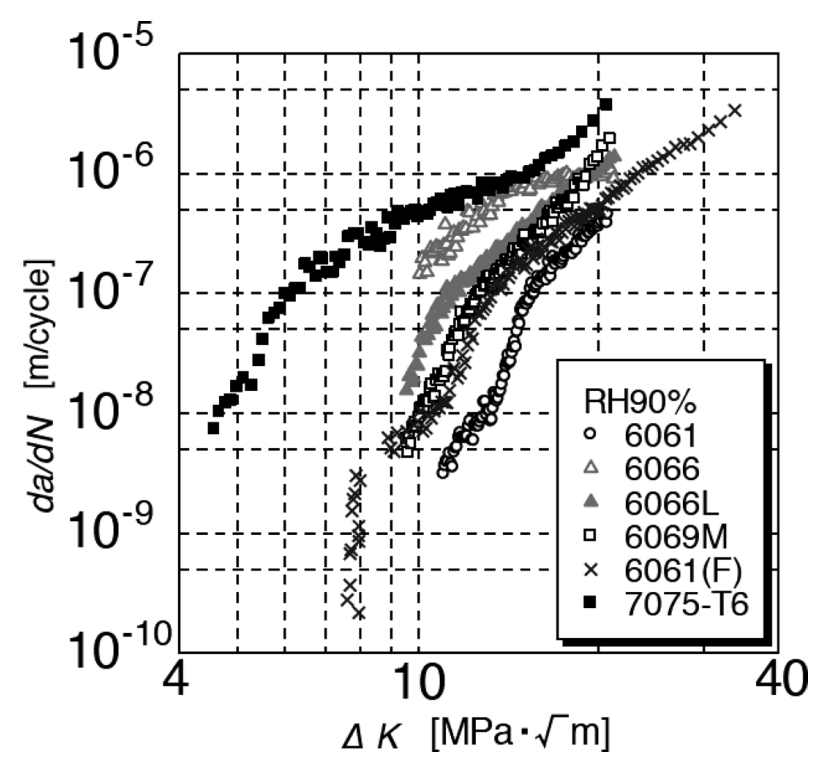

図 7 室温 RH90\% 環境における疲労き裂伝播特性 ${ }^{10)}$ （図中の $\mathrm{L} ：$ 低 $\mathrm{Si}, \mathrm{M}$ ：改良型，F：提供材）

\section{より疲労き裂は低速で進展することも示されている。}

\section{6. 高圧水素用 7000 系アルミニウム合金の開発 ${ }^{10)}$}

FCV 車両のさらなる軽量化を図る観点から, 高圧水素容器 の口金, バルブ等への高強度アルミニウム合金の適用も望ま れており，代表的な高力アルミニウム合金の一つである 7000 系合金がその候補材料となり得る。しかしながら，高強度の 7000 系合金は, 水分を含む湿潤環境において SCC に敏感で あることが古くから認識されており, その主因は, アノード 溶解ではなく水素脆化が大きく関与していると云われてい る 15),17)。したがって，7000 系合金においても水素脆化に対す る安全性の確認が重要となる。これまで, 7000 系合金のなか では，最む強度の高い合金の一つである 7075 合金，および， 強度は 7075 合金に劣るものの溶接性と押出性に優れ, 耐食 性のバランスも良好な 7003 および 7N01 合金のそれぞれの組 


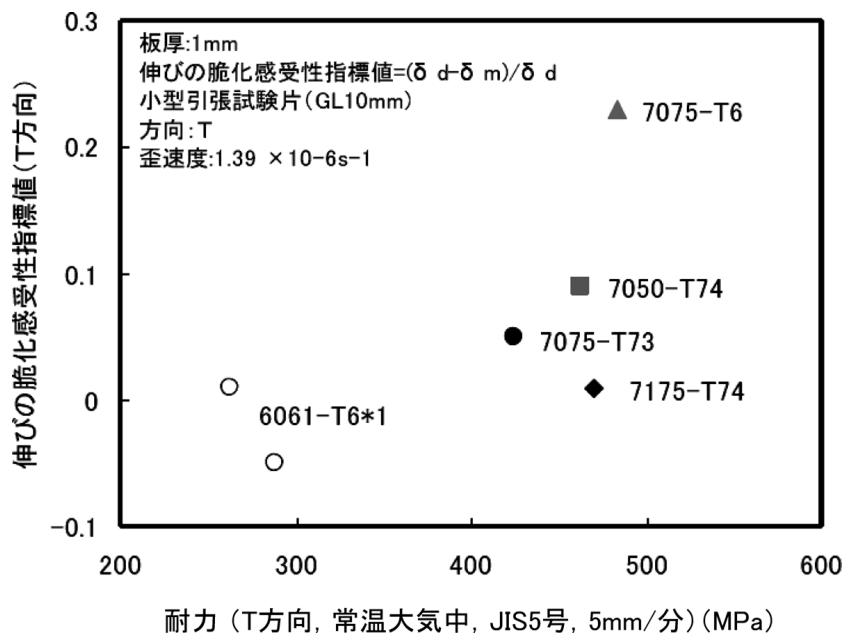

図 87000 系合金の水素脆化感受性之耐力の関係 ${ }^{10)}$

成規格内の材料について, 組織と水素脆化感受性に関する基 礎的な調查が行われている。その結果，規格中心組成の $\mathrm{T} 6$ 処理材では，伸びの脆化感受性 $I(\delta)$ を合金間で比較すると, $7 \mathrm{~N} 01(-0.08)<7003(0.41) \fallingdotseq 7075 （ 0.49 ）$ となり，特に $7 \mathrm{~N} 01$ 中 心組成材は，優れた耐水素脆性を示すことが示されている。 調質の影響としては，T6 T5 あるいは T7 処理に変更する ことによっても脆化抵抗の改善効果があることが，7003 およ び 7N01 合金でともに示されている。なお，RH $90 \%$ 雾囲気で 行われた 7003, 7N01 合金（いずれも T6 材）の疲労き裂進展 試験（周波数 $10 \mathrm{~Hz}$ ）の結果では, 疲労き裂進展速度は, 7075>7003>7N01 》6061 の順となることも示されている。す なわち，疲労き裂進展抵抗についても $7 \mathrm{~N} 01$ 合金が 7003 合金 よりあ優位にあるとされている。

一方，航空機，鉄道車両等の分野で構造材料としての実績 のある 7175 および 7050 アルミニウム合金についてあ水素脆 化感受性が調查されている。図 8 に示すように伸びの脆化感 受性 $I(\delta)$ を 7175 抢よび 7050 合金間で比較すると，6061$\mathrm{T} 6 \fallingdotseq 7175$-T74 $<7075$-T73 $<7050$-T74 $<7075$-T6 の順となること が示されている。特に 7175 合金 T74 材は 6061 合金 T6 材よ りも耐力が約 $100 \mathrm{MPa}$ ほど高いにもかかわらず 6061 合金 T6 材に匹敵するほどの耐水素脆性特性を有することが示されて いる。この 7175 合金の高い特性は，不純物元素である Fe, Si の低減規制によって晶出物量が低く抑えられていることに起 因して外部環境からの水素侵入が抑制されること，合金内部 で $\mathrm{Cr}$ に関係する分散粒子 $\mathrm{E}$ 相 $\left(\mathrm{Al}_{18} \mathrm{Cr}_{2} \mathrm{Mg}_{3}\right)$ が水素のトラッ プサイトとして作用すること，などの要因で得られているも のと推測されている。

以上より，調査された 7000 系合金の中では，最高強度の 7075 合金 T6 材が水素脆化に対して最も敏感な合金であるこ とが明らかである。そこで，高湿度大気中での SSRTによる 材料評価の精度を高めることを目的として，7075 合金 T6 板 材（板厚： $1 \mathrm{~mm}$ ）を用いて, 湿度が制御された大気中 （RH40\%, RH60\%, RH $90 \%)$ と $70 \mathrm{MPa}$ 高圧水素ガス中で行わ れたSSRT 試験により，伸びを指標として両試験雾囲気の相 関が調查されている ${ }^{9)}$ 。なお，高圧ガス中の SSRTについて は比較のために高圧窒素ガス中（70 MPa）での試験も行われ ている。湿度制御大気中および高圧ガス中の SSRT 結果を図 9 に示す。湿度制御大気中では試験湿度の増大につれて破断 (a)

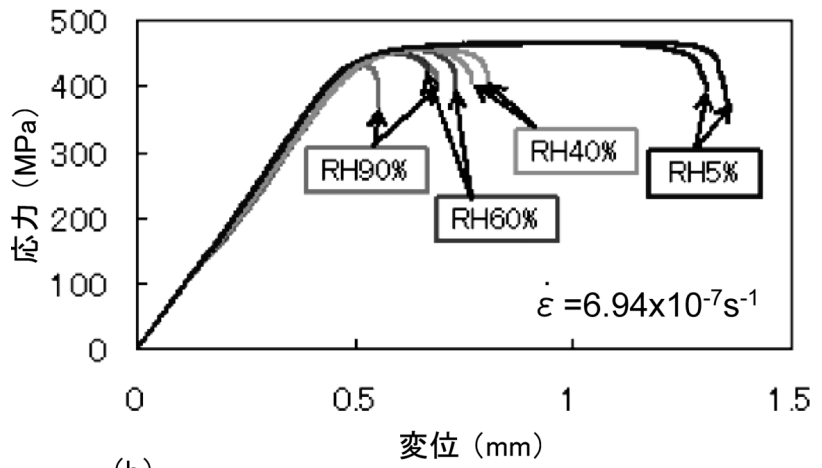

(b)

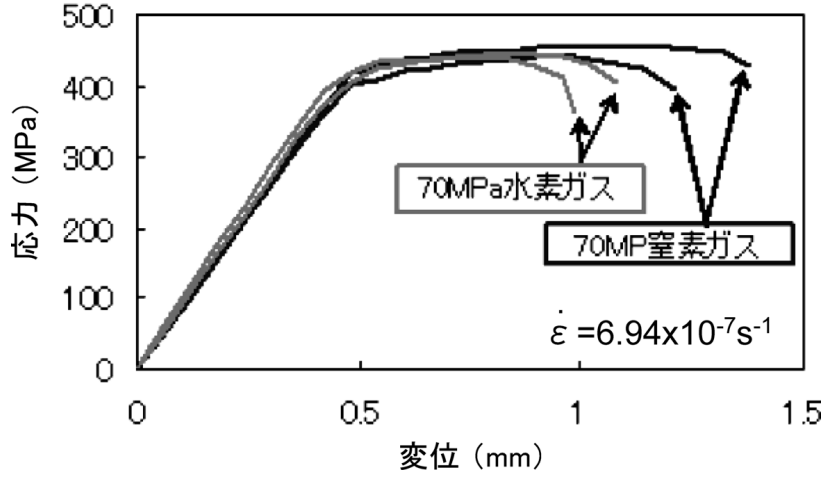

図 97075 合金 T6 材の SSRT 特性，（a）湿潤大気環境, （b） $70 \mathrm{MPa}$ 高圧水素環境 ${ }^{10)}$

(a) 70MPa窒素ガス

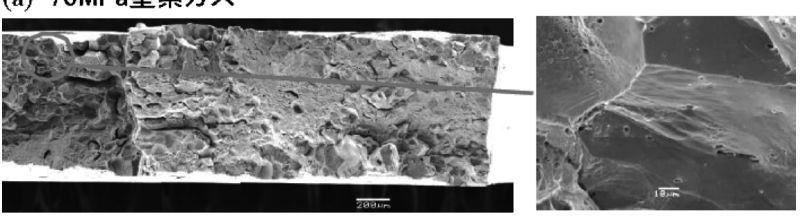

(b) 70MPa水素ガス

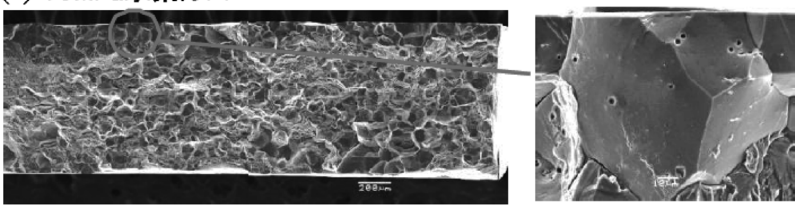

(c) $\mathrm{RH} 40 \%$

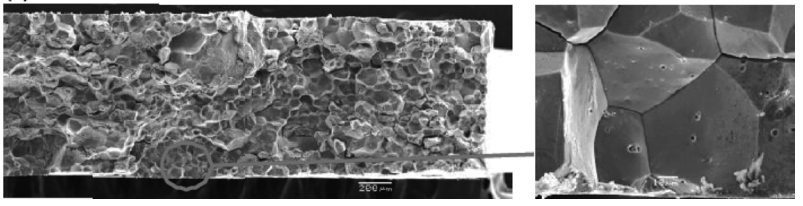

図 107075 合金の SSRT 破断組織 10

（a） $70 \mathrm{MPa}$ 窒素ガス中，（b） $70 \mathrm{MPa}$ 水素ガス中， (c) $\mathrm{RH} 40 \%$ 大気中

伸びの低下が見られる。一方, 高圧ガス中については, 比較 材の $70 \mathrm{MPa}$ 窒素ガス中の SSRT では, RH5\% 雾囲気と同程度 の破断伸びを示している。こ机に対して, $70 \mathrm{MPa}$ 水素ガス中 では, $70 \mathrm{MPa}$ 窒素ガス中と比べて, 破断伸びの低下が認めら れており, 高圧水素ガスによって脆化が生じていることが確 認されている。雾囲気ガスが破壊組織へ及ぼす影響を図 10 に示す。 $70 \mathrm{MPa}$ 窒素ガス中での破面は粒内ディンプル破面に 加えて粒界割れが一部混在した様相であり, 表面部を拡大し 


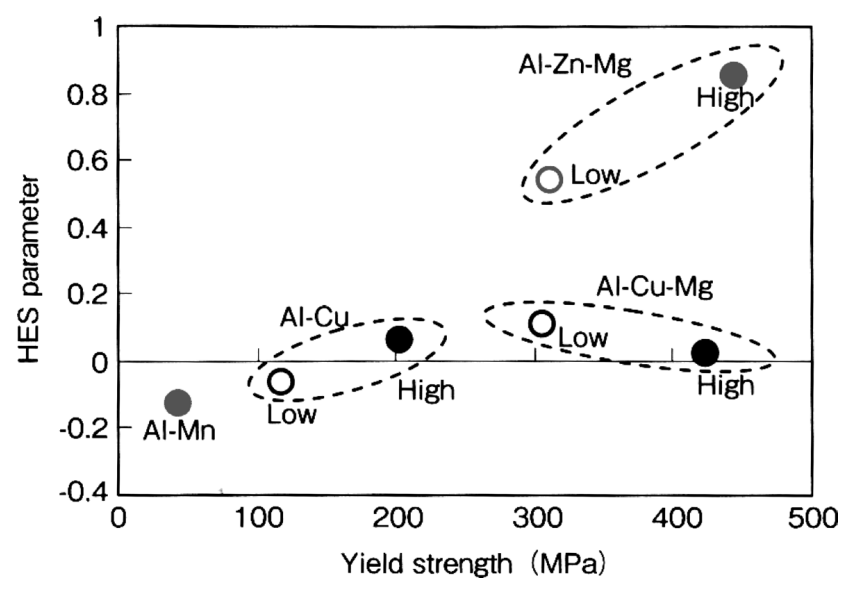

図 $11 \mathrm{Al}-\mathrm{Mn}$ および $\mathrm{Al}-\mathrm{Cu}(-\mathrm{Mg})$ 合金の水素脆化感受 性指数と耐力の関係 ${ }^{18)}$

た粒界破面においては，大きな变形が作用した延性的な痕跡 が認められる。これに対して $70 \mathrm{MPa}$ 水素ガス中で破断させ た 7075 合金の破面は粒界割れが支配的となり，とくに試験 片表面において脆性的な粒界割れが高頻度で観察されている。 明瞭な水素脆化がみられる RH $40 \%$ の湿度大気中でも同様の 脆性的な粒界割れが表面部に観察されていることから，7075 合金での高圧水素ガス中の脆化現象は高湿度大気中で見られ る機構と同じであると考えられている。また，7075 合金の破 断伸びを指標とすると, $70 \mathrm{MPa}$ 水素ガス雾囲気と湿潤大気中 の相対湿度との相対関係では， $70 \mathrm{MPa}$ の水素ガス環境は，お よそ RH $25 \%$ の大気環境に相当すると推定されている。

\section{7. その他アルミニウム合金の水素脆化感受性評 価 ${ }^{10), 18)}$}

前述まで内容の通り, 高圧水素容器ライナ材については 6000 系を中心とした合金開発が進められているが，将来的な 水素利用の拡大を想定すると用途の多様化に対応して使用さ れるアルミニウム合金種の拡大することも予想される。そこ で, 6000 系, 7000 系以外の合金系として 2000 系 ( $\mathrm{Al}-\mathrm{Cu}$ 系 および $\mathrm{Al}-\mathrm{Cu}-\mathrm{Mg}$ 系), 3000 系 (Al-Mn 系) についても, SSRT で水素脆化感受性が調査されている。図 11 は伸びの水 素脆化感受性指数（HES）と耐力の関係を合金ごとにまとめ たものである。なお，図 11 中の縦軸に示されている HES 指 数は本文の式（1）で示した指数 $I(\delta)$ とまったく同義の表現 である。図より, 合金種によって脆化感受性が大きく変化す ること, $\mathrm{Al}-\mathrm{Cu}-\mathrm{Mg}$ 合金の脆化感受性は同程度の耐力をもつ $\mathrm{Al}-\mathrm{Zn}-\mathrm{Mg}$ 合金よりも非常に小さいこと, などが示されてい る。この原因については明らかにされていないが，合金種間 の粒界き裂の進展の違いと関係している可能性があると指摘 されている。また耐力レベルは低いものの, Al-Mn 系合金の 水素脆化感受性は小さい $(I(\delta)=-0.13)$ ことも示されてい る。このことから, 2000 系, 3000 系合金についても, 高圧水 素環境で使用される部材としての適性を有しているものと考
えられている。

\section{8. おわりに}

燃料電池自動車の車載用高圧水素ガス容器のライナ候補材 料として開発が進められているアルミニウム合金の研究状況 について, 本稿で紹介させて頂いた。現在, 高圧水素用圧力 容器ライナとして使用されているのは 6061 合金 $\mathrm{T} 6$ 材のみと なっているが, 実用化の推進のためには, 現状の 6061 合金 よりあ機械的特性および而水素脆化特性のバランスに優れる アルミニウム合金を開発することで, ライナ候補材として使 用可能な合金種を増やすことが今後の課題となっている。ま た低コスト化に繋がるような材料技術の開発も同時に求めら れている。

なお，ここで紹介した内容は，新エネルギ・産業技術総合 開発機構（NEDO）の開発項目「水素社会構築共通基盤整備 事業／水素インフラ等に係る規制再点検及び標準化のための 研究開発 /水素用アルミ材料の基礎研究」(平成 17 年度 平 成 21 年度, 委員長 : 伊藤吾朗教授 (茨城大学)) の下, 社団 法人日本アルミニウム協会のご協力のもとに実施した研究成 果の一部を抜粋して紹介したものであり, デー夕等の詳細内 容については本年度発刊の報告書 ${ }^{10)}$ にて公開されている。興 味を持たれる方は，そちらを参照されたい。

\section{参 考 文 献}

1）太田健一郎, 佐藤 登監修: 燃料電池自動車の材料技術, シー エムシー出版, (2007).

2）高野俊夫：水素利用技術集成 製造・貯蔵エネルギー利用, エ ヌティーエス, (2003), 260-274.

3）稲田貴臣, 張惟敦, 江口晴樹 : 石川島播磨技報, 45（2005）, 125-129.

4）圧縮水素自動車燃料装置用容器の技術基準：JARI S001, (2004).

5）倉本 繁, 謝 明君, 菅野幹宏 : 軽金属, 52 (2002), 250-255.

6）大崎修平, 池田 淳, 木下勝之, 佐々木侑造 : 軽金属, 56 (2006), 721-727.

7) G. A. Young Jr. and J. R. Scully: Metall. Mater. Trans. A, 33 (2002), 101-115.

8）大崎修平, 前田悦宏, 木下勝之, 一谷幸司, 伊藤吾朗, 薮田 均：日本機械学会論文集 (A 編)，75（2009），366-372.

9）一谷幸司, 小山克己, 伊藤吾朗, 大崎修平, 薮田 均: 軽金属 学会第 114 回春期大会講演概要, (2008), 315-316.

10） NEDO 成果報告「水素社会構築共通基盤整備事業一水素インフ ラ等に係る規制再点検および標準化のための研究開発一水素用 アルミ材料の基礎研究」平成 17 平成 21 年度, 最終報告書 (2010).

11) H. K. Birnbaum and P. Sofronis: Mater. Sci. Eng., A176 (1994), 191202.

12) H. K. Birnbaum: Scr. Metall., 31 (1994), 149-153.

13) P. J. Ferreira, I. M. Robertson and H. K. Birnbaum: Acta Mater., 46 (1998), 1749-1757.

14) H. Vogt and M. O. Spiedel: Corros. Sci., 40 (1998), 251-270.

15）大崎修平, 池田 淳, 木下勝之, 佐々木侑造 : 軽金属, 56 (2006), 721-727.

16）伊藤吾朗, 泉 孝裕, 遠山拓史：軽金属, 58 (2008), 15-21.

17) A. Turnbull : Corros. Sci., 34 (1993), 921-960.

18）一谷幸司, 小山克己： Furukawa-Sky Review, 5 (2009), 20-28. 